\title{
THE
}

\section{Novel Use of Species Distribution Modeling to Identify High Priority Sites for American Woodcock Habitat Management}

\author{
Bill Buffum \\ University of Rhode Island, bill_buffum@uri.edu \\ Roger Masse \\ University of Rhode Island \\ Scott R. McWilliams \\ University of Rhode Island, srmcwilliams@uri.edu
}

Follow this and additional works at: https://digitalcommons.uri.edu/nrs_facpubs

\section{The University of Rhode Island Faculty have made this article openly available.}

Please let us know how Open Access to this research benefits you.

This is a pre-publication author manuscript of the final, published article.

Terms of Use

This article is made available under the terms and conditions applicable towards Open Access Policy Articles, as set forth in our Terms of Use.

\section{Citation/Publisher Attribution}

Buffum, B., Masse, R., \& McWilliams, S. R. (2021). Novel Use of Species Distribution Modeling to Identify High Priority Sites for American Woodcock Habitat Management. Northeastern Naturalist, 28(3), 233-247. https://doi.org/10.1656/045.028.0301

Available at: https://doi.org/10.1656/045.028.0301

This Article is brought to you for free and open access by the Natural Resources Science at DigitalCommons@URI. It has been accepted for inclusion in Natural Resources Science Faculty Publications by an authorized administrator of DigitalCommons@URI. For more information, please contact digitalcommons-group@uri.edu. 


\title{
Novel Use of Species Distribution Modeling to Identify High Priority Sites for American Woodcock Habitat Management
}

\author{
Bill Buffum ${ }^{1, *}$, Roger Masse ${ }^{1,2}$, and Scott R. McWilliams ${ }^{1}$
}

\begin{abstract}
Most species distribution models (SDMs) predict the probability of presence (POP) of a species at any location based on an analysis of known occurrences and environmental variables; however, such SDMs cannot predict how much the POP of a species that requires young forest would change if a new patch of young forest is created at a certain location. We developed a new SDM tool to identify and prioritize sites where forest management efforts to create young forest vegetation would likely have the most positive effect for Scolopax minor (American Woodcock), an important umbrella species for other birds that require similar habitat. The primary output of the tool was a $50-\mathrm{m}$ raster of the predicted POP in any upland forest location in the state after young forest is created. We conducted a preliminary assessment of the predictions of the tool, and concluded that our new tool can allow land managers to identify optimal locations on their properties to create young forest for woodcock, and help conservation agencies identify private landowners with suitable properties for improving woodcock habitat.
\end{abstract}

\section{Introduction}

Conservation of young forest vegetation in the northeastern US is a priority as many wildlife species require or utilize these areas (DeGraaf et al. 2006, Foster and Aber 2004, Litvaitis 2003, Schlossberg and King 2007), and their extents have been decreasing in recent decades (Buffum et al. 2011, Foster and Aber 2004). Young forest habitat, also referred to as shrubland, scrub-shrub, or early successional forest, is dominated by shrubs or trees less than $6 \mathrm{~m}$ tall with a dense understory. Many studies have linked recent declines in populations of wildlife species across the Northeast to the loss and degradation of these ephemeral vegetation types (Blomberg et al. 2009, DeGraaf and Yamasaki 2003, Endrulat et al. 2005, Foster and Aber 2004). For example, populations of 14 shrubland bird species declined in southern New England between 1996 and 2006, whereas populations of only 4 species increased (Schlossberg and King 2007). Thus, the rarity of young forest vegetation in the Northeast, along with population declines in wildlife that depend on it, has focused the attention of conservation agencies on how to most effectively manage public and private lands to increase the extent of young forest on contemporary landscapes.

The extent of young forest in the Northeast increased dramatically after the decline of agriculture in the late $19^{\text {th }}$ century as abandoned fields succeeded to

\footnotetext{
${ }^{1}$ Department of Natural Resources Science, University of Rhode Island, Kingston, RI 02881. ${ }^{2}$ Current address - Department of Fisheries, Wildlife, and Environmental Science, State University of New York College of Agriculture and Technology, Cobleskill, NY 12043. ${ }^{*}$ Corresponding author - buffum@uri.edu.
}

Manuscript Editor: Evan Adams 
forest (Foster and Aber 2004). Agricultural decline was especially dramatic in Rhode Island, where more than $85 \%$ of the land farmed in 1850 had been abandoned by 1965 (Hooker and Compton 2003). Widespread harvesting of firewood maintained a relatively large extent of young forest in the first half of the $20^{\text {th }}$ century (Lorimer 2001). However, in the late $20^{\text {th }}$ century, the extent of young forest across the Northeast started to decline as existing areas of young forest grew older and only small amounts of new young forest were created (Foster and Aber 2004, Lorimer and White 2003). For example, the extent of young forest in Rhode Island was only $3.3 \%$ of the total land area by 2008 , and was declining by $1.5 \%$ per year (Buffum et al. 2011). Dramatic declines in young forest and associated wildlife led many conservation agencies to recommend forest clearcutting to encourage the natural regeneration of young forests (Buffum et al. 2011, DeGraaf et al. 2006, Schlossberg et al. 2010). However, there is often public opposition to clearcutting because of concerns about the visual effect of clearcuts and the potential loss of habitat for species that prefer mature forests (Askins 2001, Askins et al. 2007, Berlick et al. 2002, Buffum et al. 2014, Costello et al. 2000, Gobster 2001). Therefore, conservation agencies that implement clearcutting should carefully select sites that maximize benefits to target wildlife while minimizing negative effects.

The objective of our study was to develop a new species distribution modeling (SDM) tool to identify and prioritize sites where forest clearcutting to create young forest would likely be maximally beneficial for Scolopax minor Gmelin (American Woodcock, hereafter Woodcock). A typical SDM predicts the probability of presence (POP), also referred to as relative probability of use, of a species based on an analysis of known occurrences and environmental predictor variables (Phillips et al. 2017). SDMs have been conducted for many bird species to support conservation planning, including at least 10 young-forest bird species (Blomberg et al. 2009, Brenner and McWilliams 2019, Maslo et al. 2015, Masse et al. 2014). However, a typical SDM does not directly address how habitat management at proposed sites would affect the POP of a target species. To our knowledge, the SDM tool we developed in this study is the first of its kind to predict the POP of a target species if young forest is created at a given location.

We developed the tool for Woodcock, a popular game species in the eastern US whose populations have declined by $\sim 1 \%$ per year since 1968 (Cooper and Rau 2013) as a result of the loss and degradation of young-forest vegetation (Kelley et al. 2008, McAuley et al. 2005). Woodcock may also serve as an umbrella species for other young-forest birds (Masse et al. 2014); conserving an umbrella species helps conserve a variety of other sympatric wildlife species (Fleishman et al. 2000). Our SDM tool allows land managers to identify optimal locations on their properties to create young forest for Woodcock and help conservation agencies identify private landowners with suitable properties for creating Woodcock habitat, thereby allowing for targeted outreach efforts.

\section{Field-Site Description}

We conducted this study in Rhode Island $\left(3144 \mathrm{~km}^{2}\right)$. The state is bordered on the north and east by Massachusetts, on the west by Connecticut, and on the 
south by the Atlantic Ocean. We focused this study on Woodcock because we have conducted several detailed studies of Woodcock ecology as part of an ongoing research program with the Rhode Island Department of Environmental Management (Brenner et al. 2019; Masse et al. 2013, 2014, 2015, 2019), and forest management focused on enhancing Woodcock populations also benefits other young-forest bird species (Masse et al. 2014). In addition, state, federal, and private conservation agencies in Rhode Island are implementing an active program to create young forest for Woodcock (Buffum et al. 2019).

Our new SDM tool outputs cover the entire state, but we based the tool on occurrence data obtained by tracking Woodcock during spring-summer at the Arcadia, Big River, and Great Swamp wildlife management areas (WMAs) in Kent and Washington counties. Most point locations were collected in diurnal feeding coverts, but we also included locations from males on singing grounds and nocturnal roost locations for a subset of birds. Our 13,372-ha study area included a wide diversity of land-use types, including both mature and young forests, grasslands and other herbaceous openings, and herbaceous and forested wetlands, so we believe that Woodcock occurrence data from this area can effectively guide the development of a statewide tool. Upland forests (coniferous, deciduous, and mixed) are co-dominant at Arcadia WMA, coniferous upland forest is dominant at Big River WMA, and wetland forest is dominant at Great Swamp WMA (Masse et al. 2014). Pinus strobus L. (Eastern White Pine) is the most common species in the coniferous upland forests; various Quercus spp. (oaks), Carya spp. (hickories), and Acer rubrum L. (Red Maple) are common in the deciduous upland forests; and Red Maple is the most common tree species in the wetland forests. The Rhode Island Department of Environmental Management has been clearcutting patches of forest in all 3 WMAs to help conserve Woodcock and other wildlife that require young forests.

\section{Methods}

The purpose of the SDM tool is to predict the potential effect on Woodcock POP by generation of young forest via clearcutting in any location in Rhode Island. We created the tool by modifying the existing 2018 SDM for Woodcock in Rhode Island (Buffum 2020). We used the outputs of our tool to create statewide maps of top-priority sites for creating young forests. Finally, we applied predictions of our tool to a new landscape with simulated clearcuts to evaluate the effect of habitat management in those areas and tested for correlations between the POP in the forest surrounding each simulated clearcut and the predicted POP of the SDM.

\section{SDM for Woodcock in Rhode Island}

We had prepared the existing 2018 SDM for Woodcock in 2019 by using the Maxent software package (Phillips et al. 2017) to relate 1708 Woodcock locations to contemporary 2011 environmental variables (Table 1) and project the model onto updated 2018 versions of the same environmental variables including a 2018 young-forest layer (Buffum 2020). A previous SDM had been prepared using 
a smaller number of Woodcock locations and earlier environmental variables, including a 2010 young-forest layer (Masse et al. 2013). The Woodcock locations for the 2018 SDM were obtained during 2010-2012 field studies by catching Woodcock at singing grounds in April-May, attaching VHF transmitters, and tracking their movements 3-4 times per week thru the end of August in diurnal coverts, singing grounds, and nocturnal roost sites (Masse et al. 2013, 2014).

Maxent does not require a minimum number of location points per bird, but we decided to use the same number of points per bird. We maximized the total number of location points by selecting birds with at least 28 points $(n=61)$ and randomly selecting 28 points per bird for individuals with $>28$ points. This method resulted in 1708 location points. Maxent generates randomly selected "background" points, also called pseudo-absences, that are contrasted against the presence points. The user must select the available area within which Maxent will generate the background points, which should include locations that the species could easily reach (Merow et al. 2013). We established the available area by using the ArcGIS near tool to measure the distance of each location point from the bird's singing ground,

Table 1. Environmental variables (2011 and 2018) used in the 2018 species distribution model for American Woodcock in Rhode Island. A number of existing datasets were used to create a set of statewide rasters (10-m pixels). Since the accuracy of the woodcock tracking was estimated at $18 \mathrm{~m}$ (Masse et al. 2013), the ArcGIS focal statistics tool was used to calculate the average value of each environmental variable within $18 \mathrm{~m}$.

\begin{tabular}{|c|c|c|}
\hline Name of environmental variable & Expressed as: & Source of data \\
\hline Low young forest $(<1 \mathrm{~m}$ tall) & Percent cover within $18 \mathrm{~m}$ & Forest habitat* \\
\hline High young forest ( $1-6 \mathrm{~m}$ tall) & Percent cover within $18 \mathrm{~m}$ & Young forest in RI** \\
\hline Low mature forest (6-10 $\mathrm{m}$ tall) & Percent cover within $18 \mathrm{~m}$ & Young forest in $\mathrm{RI}^{* *}$ \\
\hline High mature forest (>10 m tall) & Percent cover within $18 \mathrm{~m}$ & Young forest in $\mathrm{RI}^{* *}$ \\
\hline Impervious surface & Percent cover within $18 \mathrm{~m}$ & Land use* \\
\hline Agriculture/pasture & Percent cover within $18 \mathrm{~m}$ & Land use* \\
\hline Other open area & Percent cover within $18 \mathrm{~m}$ & Land use* \\
\hline Extremely well-drained soil & Percent cover within $18 \mathrm{~m}$ & Soil* \\
\hline Well-drained soil & Percent cover within $18 \mathrm{~m}$ & Soil* \\
\hline Poorly-drained soil & Percent cover within $18 \mathrm{~m}$ & Soil* \\
\hline Coniferous forest & Percent cover within $18 \mathrm{~m}$ & Forest habitat* \\
\hline Deciduous forest & Percent cover within $18 \mathrm{~m}$ & Forest habitat* \\
\hline Mixed forest & Percent cover within $18 \mathrm{~m}$ & Forest habitat* \\
\hline Fresh water & Percent cover within $18 \mathrm{~m}$ & Land use* \\
\hline Distance to upland young forest & Average distance $(\mathrm{m})$ within $18 \mathrm{~m}$ & Young forest in RI $2018^{* *}$ \\
\hline Distance to any young forest & Average distance $(\mathrm{m})$ within $18 \mathrm{~m}$ & Young forest in RI $2018^{* *}$ \\
\hline Distance to stream & Average distance $(\mathrm{m})$ within $18 \mathrm{~m}$ & $\begin{array}{l}\text { Freshwater rivers and } \\
\text { streams* }\end{array}$ \\
\hline Distance to moist soil & Average distance $(\mathrm{m})$ within $18 \mathrm{~m}$ & Soils* \\
\hline Distance to agriculture/pasture & Average distance $(\mathrm{m})$ within $18 \mathrm{~m}$ & Land use* \\
\hline Distance to other open area open & Average distance $(\mathrm{m})$ within $18 \mathrm{~m}$ & Land use* \\
\hline Elevation & Average elevation $(\mathrm{ft})$ within $18 \mathrm{~m}$ & Gesch et al. 2002 \\
\hline Slope & Average slope (\%) within 18 m & Masse et al. 2014 \\
\hline
\end{tabular}


which it frequently visits from March to May (McAuley et al. 2013). We calculated the average distance for all location points to singing grounds $(1296 \mathrm{~m})$ and used the ArcGIS buffer tool to delineate an area of 13,372 ha that was at least $1296 \mathrm{~m}$ from any point. The primary output of the 2018 SDM was a 10-m ArcGIS raster dataset of the 2018 Woodcock POP for the state of Rhode Island. See Buffum (2020) for more information about the preparation of the 2018 SDM.

\section{Creation of new SDM tool to predict POP after forest management}

We used Maxent v. 3.4.0 (Phillips et al. 2017) to model the POP for our new SDM tool, and ArcGIS Desktop v. 10.6 (Environmental Systems Research Institute, Redlands, CA) to prepare the environmental variables and maps. Modeling with Maxent allowed us to create a SDM based on location data and environmental variables from one time period and easily project the SDM onto a more recent or modified set of the same environmental variables. Maxent also offers the advantage of being more stable with correlated variables than stepwise regression, so it is not necessary to remove correlated variables that are ecologically relevant (Elith et al. 2011). Furthermore, a recent comparison of 4 popular models concluded that Maxent produces the best predictions and is recommended when absence data is not available (Grimmett et al. 2020).

Maxent offers a number of modeling options that can be selected by the user. We selected the cloglog transformation approach to estimate the POP, which is considered more effective at estimating POP than logistic transformation (Phillips et al 2017). We set the regularization multiplier at 1.00 , which reduces overfitting (Merow et al. 2013). We set the number of replicates at 10 and selected cross validation to evaluate the model, which offers the advantage of using all of the occurrence data for validation by randomly splitting the data into equal-sized folds and creating a series of models leaving out each fold in turn (Merow et al. 2013).

We created the tool based on the same 1708 location points as the 2018 SDM, but projected the model onto a manipulated version of the 2018 environmental variables. Other studies have assessed the effect of potential clearcuts on Woodcock POP in specific areas by simulating several clearcuts and recalculating the POP (Masse et al. 2014, 2019). However, we wanted to predict the POP after forest management anywhere in the state. It was infeasible to simulate clearcuts everywhere, so we simplified the process by identifying 2 key environmental variables in upland forests that would change if a clearcut was created nearby: (a) distance to young upland forest, and (b) distance to any young forest (upland or wetland). We created a modified set of environmental variables for our SDM tool by adjusting the values of these 2 variables in 589,300 upland forest locations evenly spaced throughout the state, but did not actually simulate any clearcuts. In these sample locations, we reset the values of both variables to $10 \mathrm{~m}$, which meant that the locations were still upland forest, but were only $10 \mathrm{~m}$ from a newly created clearcut. Then, we recalculated the POP for each sample location to see how the POP would change under these conditions.

A key challenge in developing the SDM tool was selecting sample locations for the modified attributes. If we modified the 2 variables in every pixel of upland 
forest in the state, the model would not be able to calculate the POP of the sample sites in relation to sites without modified attributes. For this reason, we selected 10 -m pixels for modification that were evenly spaced $40 \mathrm{~m}$ apart and surrounded by 24 unmodified pixels (Fig. 1). We achieved this distribution by creating a $50-\mathrm{m}$ raster of upland forest areas. We did not include wetland forests because state regulations only permit clearcuts in upland forests (Cassidy et al. 2003). We used the hydric attribute of the Rhode Island Soils dataset (RIGIS 2020) to distinguish between upland and wetland forests. Each 50-m pixel in this raster $(n=589,300)$ had an area of $2500 \mathrm{~m}^{2}$. We divided each $50-\mathrm{m}$ pixel into $10-\mathrm{m}$ pixels, each with an area of $100 \mathrm{~m}^{2}$. Then, we modified the central $10-\mathrm{m}$ pixel inside each $50-\mathrm{m}$ pixel. Thus, the 589,300 modified pixels represented $4 \%$ of 10 -m pixels in upland forests. We used Maxent to recalculate the POP for the entire state, and extracted the new POP values for the modified pixels. We then applied these new POP values to the entire 50-m pixel within which each central 10-m pixel was located. The output was a 50-m raster of all upland forest areas in Rhode Island displaying the predicted Woodcock POP if a new patch of young forest was created within $10 \mathrm{~m}$.

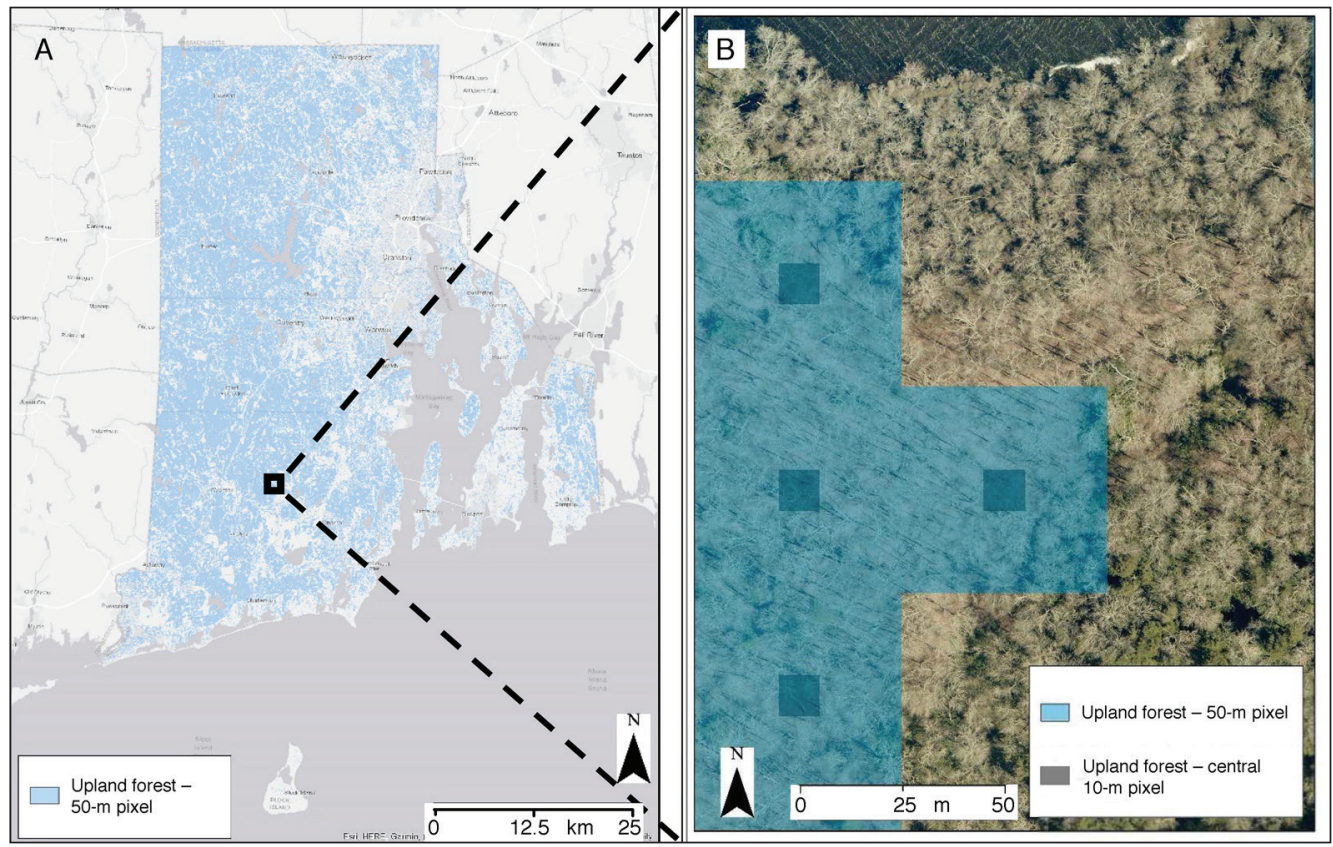

Figure 1. Selection of pixels for modification of key environmental attributes that would change if a clearcut is created in a given location. Developing the tool to predict the effect of potential clearcuts on American Woodcock probability of presence (POP) involved selecting $4 \%$ of all possible $10-\mathrm{m}$ pixels throughout the state of Rhode Island. Panels (A) and (B; a larger scale insert) include 50-m pixels of upland forest (blue). Each 50-m pixel has an area of $2500 \mathrm{~m}^{2}$, and was then divided into 25 smaller $10-\mathrm{m}$ pixels with an area of 100 $\mathrm{m}^{2}$. (B) illustrates the central $10-\mathrm{m}$ pixels (red) inside each $50-\mathrm{m}$ pixel. We only selected the central pixels $(n=589,300)$ for modification of 2 environmental variables (see Methods for details). 


\section{Additional maps to identify priority sites for forest management}

The predicted Woodcock POP after forest management provides useful information, but most land managers have limited time and resources, so they must consider where forest management could provide the most benefit. For example, some areas with a high predicted POP after forest management already have a high initial POP, so forest management would not have much additional effect. Furthermore, a significant POP increase in areas with low POP may still result in low POP after forest management. Therefore, it is important to identify sites where forest management would cause a large increase in POP and a high overall POP.

For this reason, we prepared an additional map of top-priority sites for the creation of young forests. We prepared a raster of the predicted POP increase if young forest is created in any upland forested area by using the ArcGIS raster calculator tool to subtract the current 2018 POP from the predicted POP after forest management. We then created a raster that identifies the top $20 \%$ of sites for forest management by only including sites where both the predicted POP increase after forest management and the predicted POP after forest management are in the top $20 \%$. Since some landowners may want to improve habitat for Woodcock in areas that don't include any sites in the top $20 \%$, we also created a raster that identifies the top $40 \%$ of sites for forest management by including sites where both the predicted POP increased after forest management and the predicted POP after forest management are in the top $40 \%$.

Given that the efficacy of forest management at a given site depends on ownership, we determined the ownership of the top $20 \%$ priority sites by using State Conservation Areas, and Local Conservation Areas spatial datasets (RIGIS 2020).

\section{Preliminary assessment of the SDM tool}

Over time, we plan to conduct an independent evaluation of the predictions of the SDM tool by identifying recent clearcuts that were not included in the 2018 young forest layer used to develop the tool, and conducting field studies of Woodcock in these clearcuts and the surrounding forest areas. However, we wanted to conduct a preliminary assessment of the tool before encouraging conservation agencies to use it to identify sites for clearcutting. Therefore, we simulated 762 clearcuts in randomly selected upland forest locations throughout the state, and compared the POP values in the forests adjacent to the simulated clearcuts to the predicted POP values of our SDM tool. The SDM should accurately assess the changes to Woodcock POP after the simulated clearcut and thus can be used to assess the utility of SDM tool.

We gave each simulated clearcut an area of 3 ha based on a previous analysis of the extent and size of clearcuts to create young forest in Rhode Island from 2004 to 2011 (Buffum et al. 2019). Modifying the 2018 attributes to include these clearcuts involved (a) reclassifying the land use in the simulated clearcuts from mature forest (low or high) to low young forest; and (b) using the ArcGIS near tool to recalculate the statewide variables of distance to upland young forest and distance to any young forest. We have used the same process in the past to update 
our spatial layers to include new clearcuts that have actually been created. We used Maxent to calculate the Woodcock POP for this simulated scenario using the same process described above for preparing the 2018 SDM, but projecting the model onto the modified version of 2018 environmental variables with the simulated clearcuts. Thus, the SDM tool can be assessed by comparing POP values from a simulated clearcut Maxent model and the tool itself.

Randomly selecting the locations for the simulated clearcuts involved several steps. We used ArcGIS to create polygons of "upland forest" (Fig. 2) totaling 125,987 ha by excluding areas with hydric soils. We created a smaller set of polygons of "upland forest for point selection" totaling 9800 ha, within which we could randomly select the center points of our simulated clearcuts. We used the ArcGIS buffer tool to create these polygons by (a) eliminating any area in the upland polygons that were less than $98 \mathrm{~m}$ from the border of the upland forests, so that the center of a 3-ha circular clearcut on non-hydric soils could be located anywhere in the polygon; and (b) eliminating any area that was less than $138 \mathrm{~m}$ from the border of all forests (upland and wetland), so that the border of each simulated clearcut would be at least $40 \mathrm{~m}$ from a non-forest area. We realize that Woodcock often use clearcuts next to grasslands for courtship and roosting, but since our tool was

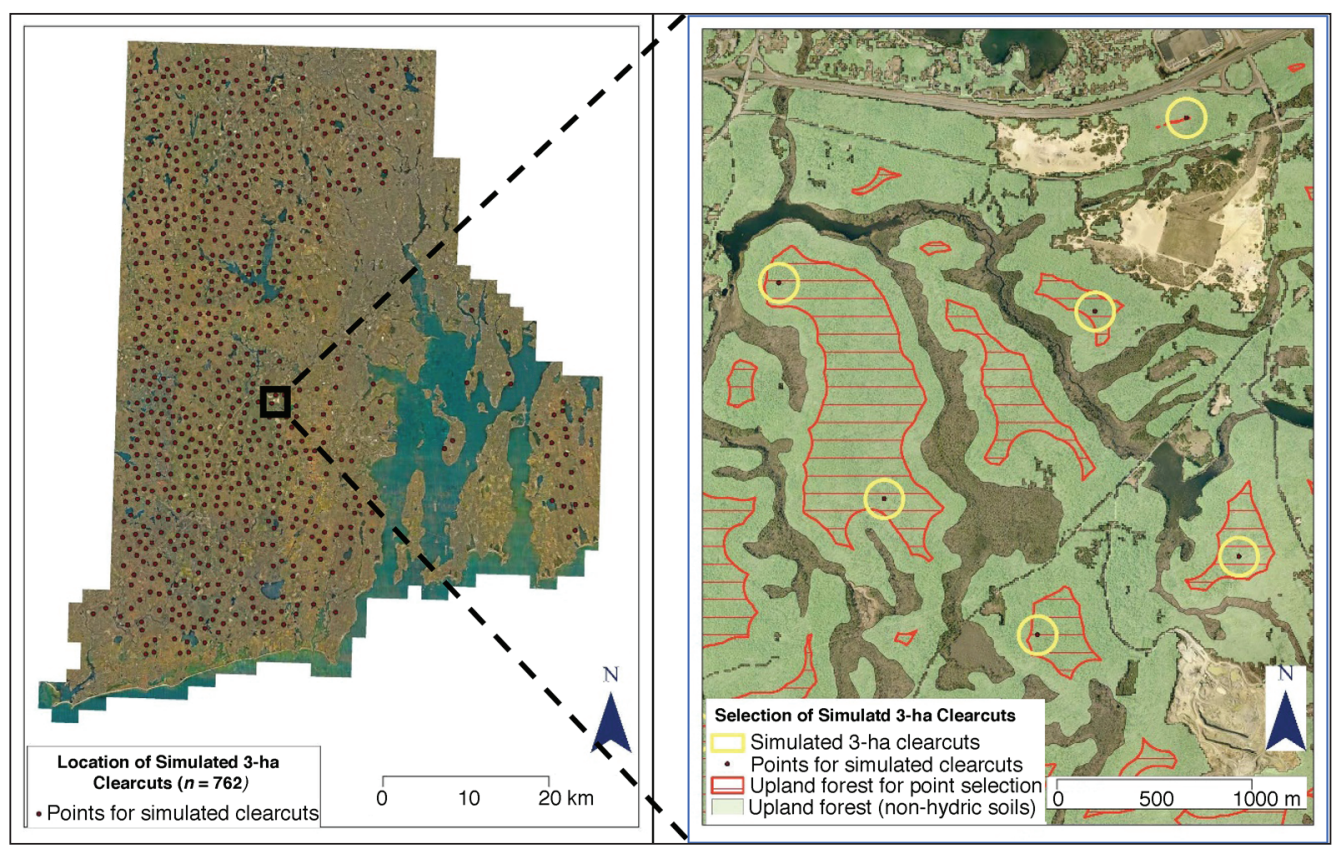

Figure 2. Selection of simulated clearcuts for evaluation of the species distribution modeling tool. Panel (A) includes the location of the 762 simulated clearcuts. Panel (B), a larger scale map, shows how the locations for the simulated clearcuts in upland forest (green polygons) were identified. Smaller areas where any randomly selected point could be the center of a 3-ha clearcut (red horizontal lines) were located in upland forest, with the clearcut border being at least $40 \mathrm{~m}$ from a non-forest area. The points for simulated clearcuts were randomly generated with a minimum distance between points of $1000 \mathrm{~m}$ (see Methods for details). 
designed to predict the POP of a forested area surrounding a clearcut, we decided that our simulated clearcuts for testing the prediction should be fully surrounded by forest. We set the minimum distance from a non-forest area at $40 \mathrm{~m}$ because our tool was based on 50-m forested pixels, some of which can include up to $49 \%$ coverage of non-forest. Thus, the $40-\mathrm{m}$ minimum distance reduced the potential for our simulated clearcuts to overlap with areas that were previously non-forest. We used the ArcGIS random points tool to generate the maximum number of points possible within these polygons that had a minimum distance between points of at least $1000 \mathrm{~m}$. We selected this minimum distance to ensure that the POP of the forests surrounding each simulated clearcut would only be affected by 1 clearcut. We used the ArcGIS buffer tool to generate circles around the resulting 762 points with a radius of $97.72 \mathrm{~m}$, which created 3-ha clearcuts (Fig. 2).

After using Maxent to calculate the Woodcock POP for this simulated scenario, we used the ArcGIS focal statistics/annulus tool to calculate the mean Woodcock POP of the forest around each simulated clearcut at 3 scales: within $40 \mathrm{~m}, 100 \mathrm{~m}$, and $200 \mathrm{~m}$ of each clearcut. Our SDM tool had been designed to predict the POP in the forest adjacent to a clearcut, so our first analysis did not include the area within the clearcuts. However, we hoped that our SDM tool would also be able to predict the POP for the area within clearcuts, which are also preferred habitat for Woodcock. So, we ran a second analysis that included the area inside the clearcuts as well as the forest around the clearcuts.

We used IBM SPSS Statistics v26 to test for correlations between the predicted POP of our new SDM tool (for the 50-m pixel which included the center of the simulated clearcut) and the simulated POP for (a) the forest area around each clearcut at the 3 scales, and (b) the clearcut and the forest area around each clearcut at the 3 scales. These values did not have normal distributions, so we used Spearman's correlation based on the median rather than mean values to evaluate the correspondence between the predicted and simulated POP across all areas.

\section{Results}

The creation of our SDM tool involved preparing 4 new state-wide ArcGIS rasters: Woodcock Upland POP 2018; Woodcock POP After Forest Mgt 2018; Increase in Woodcock POP After Forest Mgt 2018; and Top-Priority Sites for Forest Mgt. These four rasters, which can be viewed with GIS software, are publicly available on the Dryad Repository (Buffum 2021).

We present the 2 most important rasters in Figures 3 and 4. Each figure presents the data at 2 scales: a state-wide map as well as a close-up map of a portion of the Big River Wildlife Management Area in West Greenwich, RI (Lat $71^{\circ} 35^{\prime} \mathrm{W}$, Long $\left.41^{\circ} 38^{\prime} \mathrm{N}\right)$. We selected this area for presenting example results because it includes both upland and wetland forest, and is known to be occupied by Woodcock (Masse et al. 2014).

The primary output of our new SDM tool (Fig. 3) is a 50-m raster that predicts the POP in any upland forest location in the state after a clearcut is created. The Maxent model that produced this raster had an AUC score of 0.881, which is at the top end 
of the "good" category (0.8-0.9) for SDMs, and just below the "excellent" category (0.9-1.0) (Wei et al. 2018). The raster provides the exact POP values for each pixel, but for ease of interpretation in the figure we classified the POP values into 4 quantile classes, each of which includes $25 \%$ of the land area of Rhode Island.

The top priority sites for forest management (Fig. 4) is a subset of sites with high predicted POP after forest management (from Fig. 3) that also have a high predicted change in Woodcock POP after forest management. Thus, these top-priority sites do not include areas with an initial high POP that would not be further affected by the creation of a new clearcut. The Top 20\% layer shown in Fig. 4 contains 65,299 pixels $(16,306 \mathrm{ha})$, which represent $11 \%$ of the total upland forested area in the state. The Top 40\% layer shown in Fig. 4 contains another 111,545 pixels $(27,855$ ha), which represent $19 \%$ of the total upland forested area in the state (see Methods for more details).

Our analysis of the ownership of the top 20\% sites across the state revealed that these sites are owned by 4 different categories of landowners, and that private landowners own $74 \%$ of the top $20 \%$ sites (Table 2 ). A previous study analyzed the extent of young forest created in RI from 2004 to 2011 (Buffum et al. 2019) and reported private landowners created $74 \%$ of the young forest. The percent of young forest created by the landowner categories was also very similar to the percent of the top $20 \%$ sites they own (Table 2), which suggests that outreach programs to improve woodcock habitat should target all 4 landowner categories.

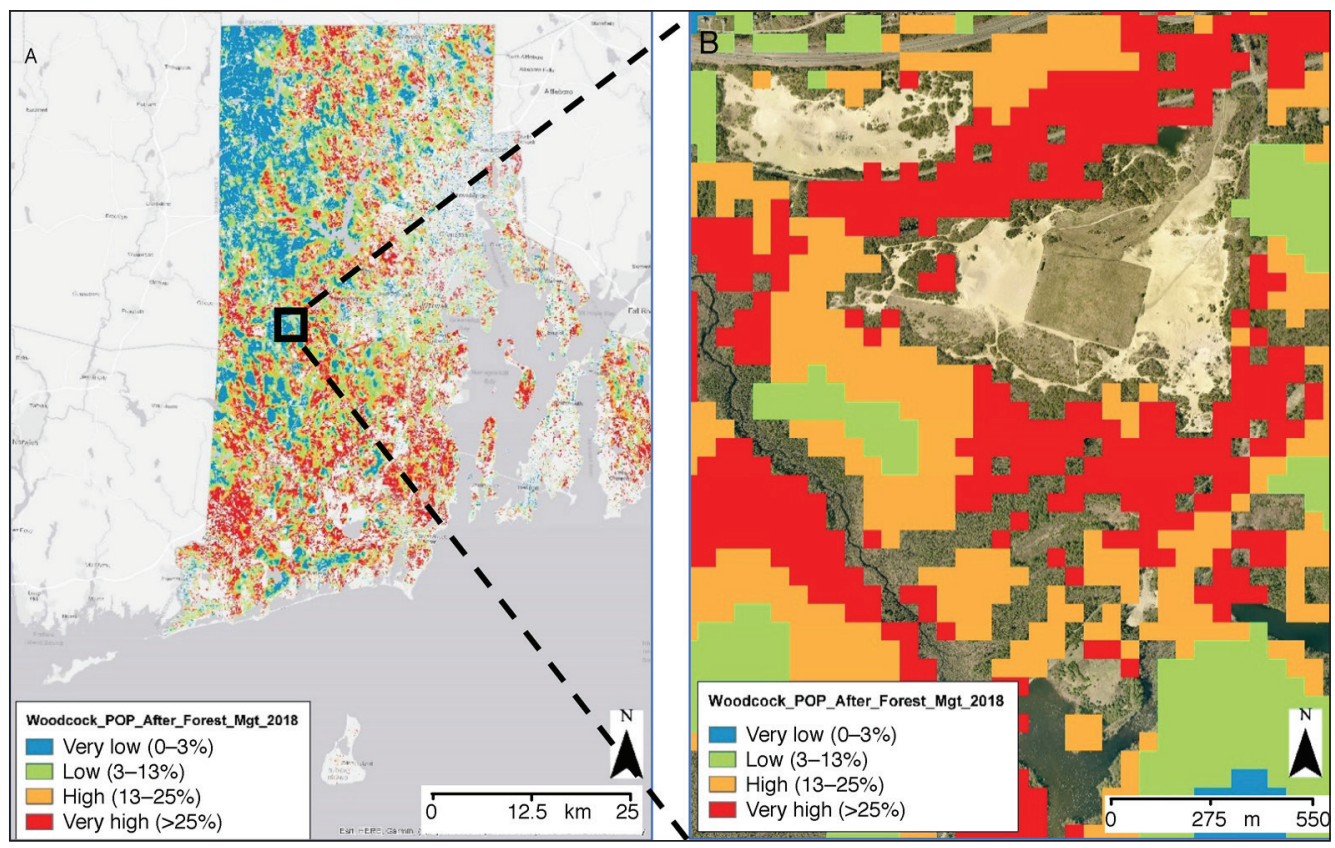

Figure 3. Predicted woodcock probability of presence (POP) after forest management (insert shows an example for a 385-ha portion of the state-owned Big River Wildlife Management Area). This raster only includes 50 -m pixels classified as upland forest (see Methods for details). The POP values are classified into 4 quantiles, each containing $25 \%$ of the total pixels. 
We conducted a preliminary assessment of the POP predictions of our new SDM tool by comparing them to the POP values around 672 simulated clearcuts. Our first analysis focused on the forest area around the simulated clearcuts. Our second analysis included the areas inside the simulated clearcuts and the surrounding forests. In both analyses, the 2 sets of POP values were highly correlated at all 3 spatial scales $(P \leq 0.001$; Table 3$)$.

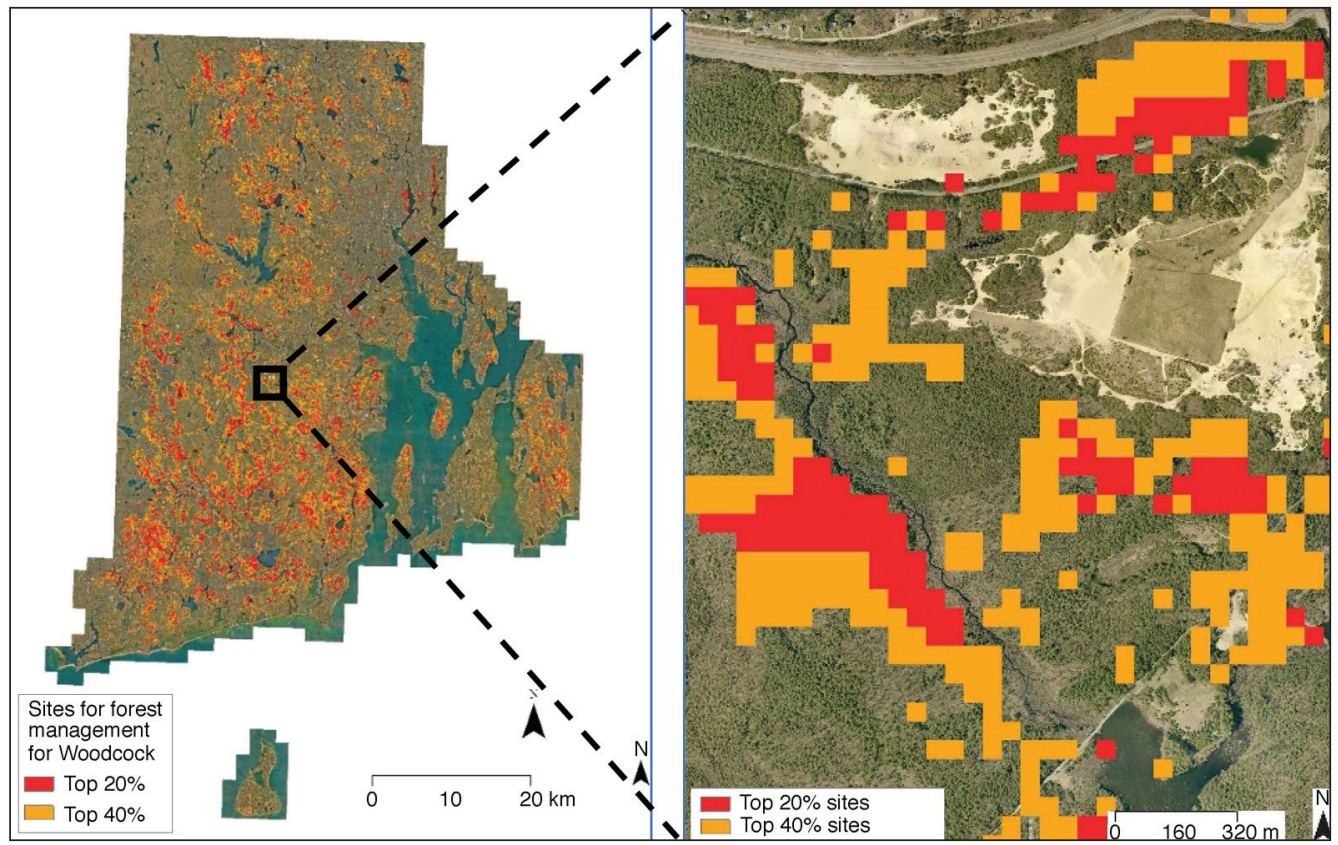

Figure 4. Top-priority sites for forest management for American Woodcock habitat (inset shows an example for a 385-ha portion of the state-owned Big River Wildlife Management Area). The top $20 \%$ category includes sites where both the predicted POP increase after forest management and the predicted POP after forest management are in the top $20 \%$ class in RI. The top $40 \%$ category includes additional sites where both the predicted POP increase after forest management and the predicted POP after forest management are in the top $40 \%$ class in RI. This raster only includes 50-m pixels classified as upland forest (see Methods for details).

Table 2. Ownership of top $20 \%$ sites and extent of young forest created in Rhode Island.

\begin{tabular}{lccrrrr} 
& \multicolumn{2}{c}{ Ownership (ha [ac]) } & & \multicolumn{2}{c}{ Ownership (\% of total) } \\
\cline { 2 - 3 } \cline { 5 - 6 } Fee ownership & Top 20\% sites & $\begin{array}{c}\text { Young forest } \\
\text { created* }\end{array}$ & & \multicolumn{2}{c}{ Top 20\% sites } & $\begin{array}{c}\text { Young forest } \\
\text { created* }\end{array}$ \\
\hline State of RI & $777.0(1920.0)$ & $22.4(55.4)$ & & $11.9 \%$ & $10.7 \%$ \\
US Fish and Wildlife Service & $14.2(35.0)$ & $1.1(2.7)$ & & $0.2 \%$ & $0.5 \%$ \\
Land trusts and NGOs & $884.2(2184.8)$ & $30.9(76.4)$ & & $13.5 \%$ & $14.8 \%$ \\
Private landowners & $4881.2(12,061.6)$ & $154.8(382.5)$ & & $74.4 \%$ & $74.0 \%$ \\
Total & $6556.5(16,201.4)$ & $209.2(517.0)$ & & $100.0 \%$ & $100.0 \%$
\end{tabular}

*Data source for young forest created (2004-2011): Buffum et al. (2019). 


\section{Discussion}

As far as we know, this is the first attempt to develop a statewide spatial SDM tool to predict the effect a new clearcut in a given location would have on the POP of a species that requires young forest. We prepared this tool to guide forest management for Woodcock primarily because they are a wildlife species of conservation interest, they have been the focus of recent spatial ecology and movement studies in the state (Brenner et al. 2019, Masse et al. 2019), and forest management focused on enhancing Woodcock populations also benefits many other species of young forest birds that face similar conservation threats (Masse et al. 2015). However, the same approach could be modified and used for any wildlife species or suite of species so long as data on the point locations for the target species and corresponding environmental data are available.

We initially prepared this SDM tool to aid the selection of sites for management on state-owned WMAs. Indeed, the Rhode Island Department of Environmental Management's Division of Fish and Wildlife currently uses this tool to select sites for clearcuts on their WMAs that will maximize the benefits for a wide range of wildlife that require young-forest vegetation. However, our analysis of the ownership of top-priority sites (Table 2) implies that this tool could also help a wide range of conservation organizations to manage their properties to benefit Woodcock. Many private landowners in Rhode Island have also expressed interest in managing their properties to improve wildlife habitat (Buffum et al. 2014, 2019). Thus, our tool could be utilized by private landowners, consulting foresters, non-profit organizations, or agencies such as the USDA Natural Resources Conservation Service that provide technical and financial support to private landowners to meet this objective.

Our assessment of the SDM tool by simulating clearcuts in randomly selected locations has demonstrated that the assumptions used to create the tool appear reasonable. However, our tool can be improved and requires an evaluation with independent data. Our 2018 SDM was almost entirely based on occurrence records of male Woodcock in 3 parts of the state. In 2020, we started a new research program

Table 3. Preliminary assessment of of the predictions of the SDM tool. Correlations between predicted POP of SDM tool and POP near simulated clearcuts $(n=672) . * *$ indicates Spearman's correlation is significant at the 0.001 level (2-tailed).

\begin{tabular}{llc} 
Analysis & \multicolumn{1}{c}{$\begin{array}{c}\text { Spatial scale of POP } \\
\text { near simulated clearcuts }\end{array}$} & $\begin{array}{c}\text { Correlation with predicted } \\
\text { POP of SDM Tool }\end{array}$ \\
\hline $\begin{array}{l}\text { Analysis 1: mean POP value for the } \\
\text { forest surrounding a simulated 3-ha } \\
\text { clearcut POP (but not including the } \\
\text { clearcut) }\end{array}$ & $\begin{array}{l}\text { Forest within 40 m of clearcut } \\
\text { Forest within 100 m of clearcut }\end{array}$ & $\begin{array}{l}0.922^{* *} \\
0.902^{* *} \\
\text { Forest within 200 m of clearcut }\end{array}$ \\
$\begin{array}{lll}\text { Analysis 2: mean POP value for both } \\
\text { the forest surrounding a 3-ha clearcut } \\
\text { and the clearcut }\end{array}$ & $\begin{array}{l}\text { Forest within 40 m of clearcut } \\
\text { Forest within 100 m of clearcut }\end{array}$ & $0.967^{* *}$ \\
& Forest within 200 m of clearcut & $0.916^{* *}$ \\
\hline
\end{tabular}


that compares the movements and habitat use of radiomarked female Woodcock in Rhode Island during nesting, brood-rearing, and post-nesting with the movements and habitat use of radiomarked male Woodcock. We plan to update our SDM tool after occurrence data is obtained for an adequate number of female Woodcock. We will also incorporate additional occurrence records of male Woodcock in other parts of the state. Further refinements can also be achieved by directly evaluating the effect of new clearcuts over time on the subsequent distribution, abundance, and movements of Woodcock over time.

\section{Acknowledgments}

This research was supported by the USDA National Institute of Food and Agriculture, McIntire-Stennis project (accession number 1019907), the University of Rhode Island, as well as by the Rhode Island Department of Environmental Management and the USFWS Wildlife and Sport Fish Restoration Program.

\section{Literature Cited}

Askins, R.A. 2001. Sustaining biological diversity in early successional communities: The challenge of managing unpopular habitats. Wildlife Society Bulletin 29:407-412.

Askins, R.A., B. Zuckerberg, and L. Novak. 2007. Do the size and landscape context of forest openings influence the abundance and breeding success of shrubland songbirds in southern New England? Forest Ecology and Management 250:137-147.

Berlick, M.M., D.B. Kittredge, and D.R. Forest. 2002. The illusion of preservation: A global environmental argument for the local production of natural resources. Harvard Forest Paper 26. Harvard Forest, Harvard University, Petersham, MA. 23 pp.

Blomberg, E.J., B.C. Tefft, E.G. Endrulat, and S.R. McWilliams. 2009. Predicting landscape-scale habitat distribution for Ruffed Grouse, Bonasa umbellus, using presenceonly data. Wildlife Biology 15:380-394.

Brenner, S.J., and S.R. McWilliams. 2019. Independence day: Post-fledging movements and behavior of adult Eastern Towhees (Pipilo erythrophthalmus) in landscapes managed for American Woodcock (Scolopax minor). Wilson Journal of Ornithology 131:796-806.

Brenner, S.J., B. Buffum, B.C. Tefft, and S.R. McWilliams. 2019. Landscape context matters when American Woodcock select singing grounds: Results from a reciprocal transplant experiment. The Condor 12(1):1-11.

Buffum, B. 2020. Species distribution modeling for American Woodcock in Rhode Island based on 2018 environmental attributes. University of Rhode Island, Department of Natural Resources Science, Kingston, Rhode Island. Available online at https://web. uri.edu/forestry/files/2021/01/Buffum_2020_RI_Woodcock_SDM_2018_Variables.pdf. Accessed 10 December 2020.

Buffum, B. 2021. GIS Rasters to identify sites for creating habitat for American Woodcock in Rhode Island. Dryad Repository. Available online at https://doi.org/10.5061/dryad. pg4f4qrp6.

Buffum, B., S.R. McWilliams, and P.V. August. 2011. A spatial analysis of forest management and its contribution to maintaining the extent of shrubland habitat in southern New England, United States. Forest Ecology and Management 262:1775-1785.

Buffum, B., C. Modisette, and S.R. McWilliams. 2014. Encouraging family forest owners to create early successional wildlife habitat in southern New England. PLoS ONE 9:6. 
Buffum, B., B.C. Tefft, R.J. Masse, and S.R. McWilliams. 2019. Mobilizing private landowners to create American Woodcock habitat: Lessons learned in Rhode Island. Pp. 168-177, In D.G. Krementz, T.R. Cooper, and D.E. Andersen (Eds.). Proceedings of the Eleventh American Woodcock Symposium. University of Minnesota Libraries Publishing, Minneapolis, MN. 269 pp.

Cassidy, G.J., J.B. Aron, and M. Tremblay. 2003. Forestry best management practices for water quality protection. Rhode Island Forest Conservator's Organization, Inc., North Scituate, RI. 36 pp.

Cooper, T.R., and R.D. Rau. 2013. American Woodcock population status - 2013. US Fish and Wildlife Service, Laurel, MD. 16 pp.

Costello, C.A., M. Yamasaki, P.J. Pekins, W.B. Leak, and C.D. Neefus. 2000. Songbird response to group selection harvests and clearcuts in a New Hampshire northern hardwood forest. Forest Ecology and Management 127:41-54.

DeGraaf, R.M., and M. Yamasaki. 2003. Options for managing early successional forest and shrubland bird habitats in the northeastern United States. Forest Ecology and Management 185:179-191.

DeGraaf, R.M., M. Yamasaki, W.B. Leak, and A.M. Lester. 2006. Technical Guide to Forest Wildlife Habitat Management in New England. University Press of New England, Hanover, NH. 306 pp.

Elith, J., S.J. Phillips, T. Hastie, M. Dudík, Y.E. Chee, and C.J. Yates. 2011. A statistical explanation of MaxEnt for ecologists. Diversity and Distributions 17:43-57.

Endrulat, E.G., S.R. McWilliams, and B.C. Tefft. 2005. Habitat selection and home-range size of Ruffed Grouse in Rhode Island. Northeastern Naturalist 12:411-424.

Fleishman, E., D. D. Murphy, and P.F. Brussard. 2000. A new method for selection of umbrella species for conservation planning. Ecological Applications 10:569-579.

Foster, D.R., and J.D. Aber. 2004. Forests in Time: The Environmental Consequences of 1000 Years of Change in New England. Yale University Press, New Haven, CT. 448 pp.

Gesch, D., M. Oimoen, S. Greenlee, C. Nelson, M. Steuck, and D. Tyler. 2002. The national elevation dataset. Photogrammetric Engineering and Remote Sensing 68:5-32.

Gobster, P.H. 2001. Human dimensions of early successional landscapes in the eastern United States. Wildlife Society Bulletin 29:474-482.

Grimmett, L., R. Whitsed, and A. Horta. 2020. Presence-only species distribution models are sensitive to sample prevalence: Evaluating models using spatial prediction stability and accuracy metrics. Ecological Modelling 431:109194.

Hooker, T.D., and J.E. Compton. 2003. Forest ecosystem carbon and nitrogen accumulation during the first century after agricultural abandonment. Ecological Applications 13:299-313.

Kelley, J., S. Williamson, and T.R. Cooper (Eds.). 2008. American Woodcock conservation plan. Wildlife Management Institute, Cabot, VT. 162 pp.

Litvaitis, J.A. 2003. Are pre-Columbian conditions relevant baselines for managed forests in the northeastern United States? Forest Ecology and Management 185:113-126.

Lorimer, C.G. 2001. Historical and ecological role of disturbance in eastern North American forests: 9000 years of change. Wildlife Society Bulletin 29:425-439.

Lorimer, C.G., and A.S. White. 2003. Scale and frequency of natural disturbances in the northeastern US: Implications for early successional forest habitats and regional age distributions. Forest Ecology and Management 185:41-64.

Maslo, B., J.L. Lockwood, and K. Leu. 2015. Land-ownership patterns associated with declining forest birds: targeting the right policy and management for the right birds. Environmental Conservation 42:216. 
Masse, R.J., B.C. Tefft, J.A. Amador, and S.R. McWilliams. 2013. Why woodcock commute: Testing the foraging-benefit and predation-risk hypotheses. Behavioral Ecology 24:1348-1355.

Masse, R.J., B.C. Tefft, and S.R. McWilliams. 2014. Multiscale habitat selection by a forest-dwelling shorebird, the American Woodcock: Implications for forest management in southern New England, USA. Forest Ecology and Management 325:37-48.

Masse, R.J., B.C. Tefft, and S.R. McWilliams. 2015. Higher bird abundance and diversity where American Woodcock sing: Fringe benefits of managing forests for woodcock. Journal of Wildlife Management 79:1378-1384.

Masse, R.J., B.C. Tefft, B. Buffum, and S.R. McWilliams. 2019. Habitat selection of American Woodcock and its implications for habitat management where young forests are rare. Pp. 168-177, In D.G. Krementz, T.R. Cooper, and D.E. Andersen (Eds.). Proceedings of the Eleventh American Woodcock Symposium. University of Minnesota Libraries Publishing Minneapolis, MN. 269 pp.

McAuley, D.G., J.R. Longcore, D.A. Clugston, R.B. Allen, A. Weik, S. Williamson, J. Dunn, B. Palmer, K. Evans, W. Staats, G.F. Sepik, and W.W. Halteman. 2005. Effects of hunting on survival of American Woodcock in the Northeast. Northeast Journal of Wildlife Management 69:1565-1577.

Merow, C., M. J. Smith, and J.A. Silander Jr. 2013. A practical guide to MaxEnt for modeling species' distributions: What it does, and why inputs and settings matter. Ecography 36:1058-1069.

Phillips, S.J., R.P. Anderson, M. Dudík, R.E. Schapire, and M.E. Blair. 2017. Opening the black box: An open-source release of Maxent. Ecography 40:887-893.

Rhode Island Geographic Information System (RIGIS). 2020. Rhode Island maps and data. University of Rhode Island, Kingston, Rhode Island. Providence RI. Available online at http://www.rigis.org/. Accessed 29 October 2020.

Schlossberg, S., and D.I. King. 2007. Ecology and management of scrub-shrub birds in New England: A comprehensive review. Natural Resources Conservation Service, Resource Inventory and Assessment Division, Beltsville, MD. 122 pp.

Schlossberg, S., D.I. King, R.B. Chandler, and B.A. Mazzei. 2010. Regional synthesis of habitat relationships in shrubland birds. Journal of Wildlife Management 74:1513-1522.

Wei, B., R. Wang, K. Hou, X. Wang, and W. Wu. 2018. Predicting the current and future cultivation regions of Carthamus tinctorius L. using MaxEnt model under climate change in China. Global Ecology Conservation 16:e00477. 